\title{
Thyroid Gland Mixed Medullary and Follicular Cell Carcinoma
}

National Cancer Institute

\section{Source}

National Cancer Institute. Thyroid Gland Mixed Medullary and Follicular Cell Carcinoma.

NCI Thesaurus. Code C46104.

A primary carcinoma of the thyroid gland containing a medullary carcinoma component

that is immunohistochemically positive for calcitonin, and follicular cell carcinoma

structures that are immunohistochemically positive for thyroglobulin. 